Arndt-Corden Department of Economics

Crawford School of Public Policy

ANU College of Asia and the Pacific

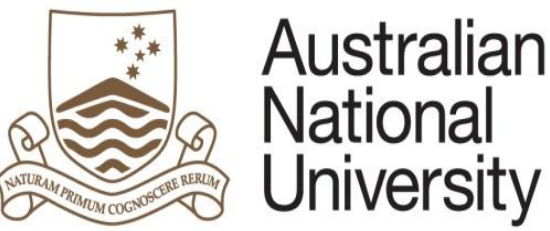

\title{
Economist as public intellectual: Max Corden's journey through life
}

\author{
Prema-chandra Athukorala \\ Australian National University \\ Hal Hill \\ Australian National University
}

Sisira Jayasuriya,

Monash University

March 2021

Working Papers in Trade and Development

No. 2021/11 
This Working Paper series provides a vehicle for preliminary circulation of research results in the fields of economic development and international trade. The series is intended to stimulate discussion and critical comment. Staff and visitors in any part of the Australian National University are encouraged to contribute. To facilitate prompt distribution, papers are screened, but not formally refereed.

Copies are available at https://acde.crawford.anu.edu.au/acde-research/workingpapers-trade-and-development 


\title{
Economist as Public Intellectual: Max Corden's Journey through Life*
}

\author{
Prema-chandra Athukorala \\ prema-chandra.athukorala@anu.edu.au
}

Hal Hill**

Hal.hill@anu.edu.au

Sisira Jayasuriya

sisira.jayasuriya@monash.edu

\begin{abstract}
:
This paper examines the intellectual contributions of Professor W. M. ('Max') Corden to Economics. We focus on three main fields: trade theory and practice, especially his pioneering work on the theory of effective protection; open economy macroeconomics, including exchange rate policy, the international monetary system, Dutch Disease, and economic crises; and Australian economic policy. We emphasize Max's motivation for working on these topics, as he sought to understand real-world economic issues and challenges, and to employ economic theory and expositional clarity in search of policy reform. We also draw attention to his personal life history, and how it has shaped his thinking on major economic and political questions.
\end{abstract}

Key words: Max Corden, trade theory, open economy macroeconomics, biography, public policy, Australia.

JEL codes: A11, B31, Z18

* We are most grateful to David Greenaway for prompting us to write this article and for his assistance with an earlier draft.

${ }^{* *}$ Corresponding author.

Forthcoming in The World Economy 


\section{Economist as Public Intellectual: Max Corden's Journey through Life}

\section{Introduction}

For over six decades Max Corden has been an intellectual giant in the Economics profession, making seminal contributions in the fields of international economics, macroeconomics, and Australian economic policy. His highly informative memoir Lucky Boy in the Lucky Country (Corden, 2017) not only summarizes his major intellectual contributions but also provides a picture of the man behind the academic writings - his unusual personal history, his acquaintances, the life he led at five universities, and perhaps most importantly what motivated him to work on the topics he focused on. ${ }^{1}$

The purpose of this paper is to broaden our understanding of Max Corden's principal contributions to the present state of Economics as a discipline through the prism of the Lucky Boy. We commence with a brief scene-setting overview of his personal history, how he got into international economics and trade policy, and his place in the Economics profession. The following two sections examine his major contributions in the field of international trade theory and open economy macroeconomics. Section 5 focuses on Max's contributions to economic analysis and policy in Australia, and their

1 This paper draws on Max Corden's voluminous writings, and particularly his 2017 memoir. Unless otherwise indicated, all quotations are taken from this book.

Of particular note also are his personal website, www.maxcorden.com (actively maintained through until around 2017), and his conversations with long time friend and former student Bob Gregory (available at https://nla.gov.au/nla.obj-209276034/listen), and with William Coleman (2006).

For readers unfamiliar with Australia, the 'Lucky Country' refers to a famous Australian book by Donald Horne (1964). 
connections to his broader theoretical work. The paper concludes with a discussion of his contributions to the Economics profession, and lessons from his work in using theoretical and applied economic analysis to inform better public policy.

\section{Setting the Scene}

Warner Max Corden (or Werner Max Cohn, his birth name) was born in 1927 in Breslau, Prussia, now known as Wroclaw in modern-day Poland. ${ }^{2}$ Raised in a comfortable, secular Jewish household, by the late 1930s their situation had become untenable. In 1937 the family took the decision to progressively flee to the safety of England, where they had relatives. Max and his brother went first, individually, followed later and with great difficulty by their parents. (His father was imprisoned briefly in the Buchenwald concentration camp.) The boys then attended school in London, and learnt English. By late 1938, the family was able to obtain visas for Australia. Reflecting on these events, and the tragic fate of other family members and friends, Max observes that 'I have never ceased being aware of our luck in getting out in time. ... The experience has affected me permanently.'

The family arrived, penniless, in Australia in early 1939, and settled in Melbourne. The city is home to the country's largest Jewish community, and its business and charitable networks assisted the family with housing and employment. The family were 'reffos' (refugees) in local parlance, but apart from the father's wartime absences they had a settled if 'quite poor' existence. Fortuitously their neighbourhood secondary school was the famous Melbourne High School, of which he has a 'fond memory'. In 1945 Max

2 The ANU department that Max headed was subsequently named the ArndtCorden Department of Economics, in recognition of its two founding heads. By remarkable coincidence, Arndt $(\mathrm{H}$. W. Arndt) also spent his childhood in Breslau before he too had to leave Germany. The two only discovered their common city of birth in the late 1950s in Canberra. 
graduated with flying colours, obtaining a General Exhibition (prize), which provided a Melbourne University scholarship and college residence.

At university Max wanted to study his first love, history, but at the behest of his father, he enrolled in a 'practical' commerce degree. (History could be his 'hobby', his father suggested.) He was 'utterly bored' by accounting and commercial law, but enjoyed Economics, including Robinson's The Economics of Imperfect Competition, Pigou's The Economics of Welfare, and Keynes's General Theory. He became an enthusiastic Keynesian, inspired also by Richard Downing, a much admired lecturer and prominent player in Australian policy discourse at the time. His politics were 'Fabian or moderate labour' (Coleman, 2006, p.381). At university he was one of the founders of the Australian Labor Party Club (ALP Club), which was a breakaway from the Communist-dominated Labor Club. His anti-communist views were influenced by his father's views and by reading about the purges, famines and authoritarianism in the Soviet Union.

Graduating with first class honours, he worked for three years for a newspaper and as a public servant while continuing with a part time Masters degree. He even flirted with a career in journalism, which perhaps explains his lifetime attention to expositional clarity and interest in the media. His Masters thesis, 'The Economics of the Australian Press', resulted in his first scholarly publication, in the Review of Economic Studies in 1952. In 1953 he secured a British Council scholarship and entry to the London School of Economics. He was on the path to becoming a professional economist.

At the LSE he was fortunate to have James Meade as his supervisor. He had already read and thoroughly absorbed Meade's magnum opus The Balance of Payments. He embarked on a dissertation entitled 'Population Increase and Foreign Trade', a topic inspired by the debates about high levels of immigration to Australia. (Sometimes referred to as the 'populate or perish' argument.) Looking back, Max regards the dissertation as very clearly written but 'boring'. His examiners were two of the greatest intellectual influences on his work and life, Meade and Harry Johnson. He regarded Johnson as his 
'life-long patron saint'. During these LSE days Max also forged close links with several brilliant young economists there, who became major figures in the international economics profession, including Robert Mundell, Kelvin Lancaster, Richard Lipsey, Tad Rybczynski, Peter Kenen and others.

Upon graduation Max returned to a Melbourne University lectureship in 1958. We now take up his career as a professional economist in three countries, four universities, and under three broad headings.

\section{International Trade}

Max had followed the debates in Australia on trade policy dating from the famous 1929 Brigden Report (The Australian Tariff: An Economic Enquiry). $\mathrm{He}$ had begun research on trade protection in earnest while in London working at the National Institute of Economic and Social Research. This resulted in two important papers published in 1957 (in Economica and the Economic Record) on tariffs, subsidies, domestic distortion theory, and the costs of protection. On returning to Melbourne he immediately renewed his interest in Australian tariff policy, 'a hot issue' in the country, which had a long history of import barriers, and had then, along with New Zealand, the highest levels of protection in the OECD. The system was highly complex, opaque and politicized. There was import licensing and other non-tariff barriers superimposed on an already complex tariff structure (Rattigan, 1986). Max's approach to the issues was guided by clear analytics combined with an understanding of the political and institutional complexities that underpinned the system. ${ }^{3}$

\footnotetext{
${ }^{3}$ In fact, Max learned first-hand about the complexity of the system from his father, who by then was an agent and wholesaler for ladies' handbags and other fashion goods, and who often talked about 'the disruptive and worrying effects of frequent changes in the import licensing system.'
} 
He quickly came to the conclusion that the key to understanding the costs and effects of Australia's convoluted system of protection was the concept of effective protection, that takes into account protection on not only the final good but also on inputs. In two local publications, not widely circulated beyond Australia, he first introduced the concept of the effective rate of protection $(E R P)$. As a result of his research, Australia's Tariff Board (and later their equivalent agencies in other countries) began to calculate effective rates for all major industries on a regular basis.

This work attracted international attention with Max's 1966 Journal of Political Economy paper, 'The Structure of a Tariff System and the Effective Protective Rate'. ${ }^{4}$ The major contribution of the paper was the development of a multicommodity general equilibrium framework, which took the exchange rate into account in determining the overall protective effect of the policy regime. It has become one of the most enduring and cited papers in international economics, and it put Max on the international stage. The paper was further refined and developed, and all the measurement and related issues examined, in his first major volume, The Theory of Protection (1971). ${ }^{5}$

Many countries adopted this new approach to measuring the effects of trade policy. The innovation had transformative effects, especially in the developing world where import protection was typically the highest. The concept of ERP

4 The history of the JPE paper might serve as encouragement to aspiring young authors. It was rejected by the Economic Journal. Max then sent it to his mentor Harry Johnson, one of the JPE editors. Johnson 'made many suggestions for improvement ... [resulting] in a much better article than the original one.'

${ }^{5}$ Max's deep insights into the effects of protection in a general equilibrium setting continues to inspire new methodological innovations; for example, in a recent paper Amiti, Kong and Weinstein (2021) show that it can be used to analyse how a tariff announcement (such as the US trade sanctions on China) affects expected total factor productivity, stock prices, and welfare. 
and its many extensions have significantly contributed to policy making at the individual country-level and in international trade policy negotiations (Anderson 2003). Despite the limitations of the concept of ERP, owing to its partial equilibrium nature, it has forced policy makers to think in general equilibrium terms, to consider the impact of trade restrictions on both imports and exports, inputs and outputs, and the trade regime in relation to the general incentive structure. Its durability and widespread application is also due to its simplicity and relatively modest data requirements (Greenaway and Milner 2003).

Max extended his work on international trade theory in several directions from the mid 1960s. In an attempt to keep up with the literature, in 1963-64 he commenced work on a major survey article on the subject. The paper was published in 1965 in the Princeton Special Papers in International Economics series and had a wide international readership for many years. He later wrote two other major survey articles on trade theory: 'The Normative Theory of Trade' (1984), which gives a thorough exposition of optimum intervention theory and proposes socially optimal policies subject to constraints that were politically determined; and 'Strategic Trade Policy' (1986) which produced a balanced assessment of how new is the 'new trade theory' viewed against the backdrop of mainstream trade theory. Much of this work also appeared in his Trade Policy and Economic Welfare (1974 and the subsequent edition in 1997), which stands as one of the clearest and most rigorous analyses of the welfare implications of alternative trade interventions. Max regards this very widely read, essentially normative economics text as his 'most ambitious enterprise'. In this book, he introduced the concept of the 'conservative social welfare function', which facilitates an understanding of the rationale for the apparently 'non-rational' policies that countries actually follow.

Two other contributions to international trade theory also deserve mention. The first is work with Ronald Findlay (Corden and Findlay, Economica, 1975) that extended the well-known Harris-Todaro model to allow for intersectoral capital mobility. The Harris-Todaro model presents a simple general equilibrium model consisting of urban and rural sectors, in which equilibrium is 
characterized by persistent unemployment in the urban sector. The CordenFindlay extension, widely cited in the development economics literature, aligned the model more closely with the Heckscher-Ohlin-Samuelson model of international trade. The second is his 1971 Journal of Political Economy paper, 'Economies of Scale and Customs Union Theory' that, as the title implied, introduced economies of scale to customs union theory. This extension paved the way for the analysis of the cost reduction and tradesuppression effects of a customs union. Interest in this paper has revived in recent decades with the new emphasis on regional economic integration and preferential trading agreements.

\section{Open Economy Macroeconomics}

After his LSE graduation, and following his two great mentors Johnson and Meade, Max continued to work at the intersection of international trade and the balance of payments, a field that later became known as open economy macroeconomics. The role of import restrictions as an instrument of balance of payments adjustment was the subject of a co-authored paper in the Economic Journal (Corden and Hemming, 1958). As mentioned, the exchange rate was a key variable in his ERP analytical framework. Two years later a paper (Review of Economic Studies, 1960) introduced the so-called dependent economy model, an Australian invention, to an international audience and the mainstream open economy macroeconomics literature.

The dominant theme in Australian macroeconomic policy discussions and debates at that time was how balance of payments disequilibria could be addressed while maintaining full employment (that is, external and internal balance). Australian economists, particularly the ANU's Trevor Swan, continuing an even earlier tradition starting with Roland Wilson's 1930 Chicago doctorate, questioned the conventional macroeconomic theories of balance of payments adjustment that focused on policies to alter the relative price of exports to imports. For countries such as Australia that were too small to affect prices in international markets, clearly this offered no practicable 
policy option. In two papers, not published until the early 1960s but presented in seminars in 1953 and 1955 and widely discussed in Australia, Swan argued that the key adjustment mechanism was through changes in the ratio of the international price level relative to domestic money wages (termed the 'cost ratio') for small, 'dependent economies', that is, countries whose international terms of trade were exogenously determined in world markets. He illustrated his model with what had come to be known as the 'Swan Diagram'. Salter, Swan's younger colleague, extended and formalized the model (drawing on his 1956 Cambridge doctorate), focusing on the relative price of domestic goods to international goods, holding the terms of trade constant, and treating imports and exports as a composite good.

The 1960 'small dependent economy model' (the 1960 RES paper), with its emphasis on an adjustment mechanism based on the internal relative price of domestic (non-traded) goods to international (traded) goods, attracted considerable international attention. This was in part owing to its use by Max's mentor Harry Johnson, 'the builder of the intellectual bridge', then teaching at the University of Chicago. In turn, Rudiger Dornbusch, a Chicago graduate, drew extensively on it in a 1974 paper (Dornbusch 1974), and devoted a full chapter in his Open Economy Macroeconomics (Dornbusch 1980), with the Corden (1960) dependent economy model as the key reference. The relative price of non-traded goods to traded goods came to be described as 'the real exchange rate' following Berglas and Razin (1973). The 'dependent economy model' is now known in the mainstream literature as the 'Australian model', or the Salter-Swan-Corden-Dornbusch model (Corbo and Fisher 1995). ${ }^{6}$

By the mid-1970s Max had more or less completed his trade work and he decided to make the 'Big Switch' to international macroeconomics. Like his work on trade policy it 'reflected [his] inclination to choose my research topics with the aim of sorting out current real-world issues.' Several other factors explain why Max, by then at Oxford, chose to work mainly on

\footnotetext{
${ }^{6}$ For a fascinating analytical history of the Salter-Swan-Corden-Dornbusch model, see Metaxas and Weber (2016).
} 
macroeconomics from this period. There were the global economic ills of that decade, the breakdown of the Bretton Woods system, adjustment to the OPEC oil shocks, stagflation and slowing economic growth, and the need for international recycling of current account surpluses. European monetary integration was in prospect. Britain was grappling with the deindustrialization consequences of the North Sea oil boom, aggravated by sterling appreciation caused by monetary tightening. Moreover, as will be explained shortly, 'Dutch Disease' became a major global research topic. He was also influenced by the work of one of his closest Oxford colleagues, Peter Oppenheimer. As this work progressed his interests extended in several directions, including exchange rate policies and debt crises. He also began to develop his ideas via conference and lecture invitations, including in particular two major events at Princeton and Chicago, which resulted respectively in Monetary Integration (1972) and Inflation, Exchange Rates and the World Economy (1977). ${ }^{7}$ As discussed in the next section, from the late 1970s he also became involved in Australian macroeconomic policy debates for extended periods.

We now examine some facets of this work in more detail. ${ }^{8}$

\section{Dutch Disease}

Max became interested in this topic in the 1970s, when commodity booms (in particular oil discoveries and rising oil prices) attracted much policy and public interest, especially because they seemed to be accompanied by the shrinking of traditional manufacturing sectors, so-called 'deindustrialization'. In

7 An expanded second edition was published in 1997 under the title, Economic Policy, Exchange Rates, and the International System.

8 In passing it is worth noting that one of Max's equally famous contemporaries in the field of international economics, Anne Krueger, also progressively made the transition to open economy macroeconomics. The two have never formally collaborated, although they have both held positions at the International Monetary Fund and Johns Hopkins School of Advanced International Studies (SAIS), and collaborated in the launching of the 1984 World Bank project on debt crises. 
particular, how and why could a country's favourable movements in its terms of trade (and hence national income) be considered a 'disease'? The answer of course is that non-booming tradable sectors become less competitive, through nominal exchange rate appreciations and/or rising domestic costs as the 'booming sector' attracts resources away from them. As noted, the topic entered the public policy domain in Britain while Max was at Oxford. It has also been a central, recurring policy issue in Australia ever since European settlement. During the 1970s minerals boom it had again surfaced as a major policy issue as Max returned to the ANU in 1976.

Two locally influential published articles by notable Australian economists and close friends (and former students) of Max - Bob Gregory and Richard Snape - attracted his attention. Max integrated the main insights from both articles and formalized and extended the analysis, authoring or co-authoring six papers on the subject in the first half of the 1980s. Of these, the most influential, and reportedly his most-cited paper, is his 1982 Economic Journal article, co-authored with a former Oxford student (and subsequently staff member), Peter Neary. In passing he regarded this paper as 'a very successful collaboration between two complementary academics', as his coauthor provided an 'impressive Mathematical Appendix'. His 1984 survey paper in Oxford Economic Papers is also widely cited. In essence, the basic Corden-Neary analysis presented a brilliant application and extension of the Australian model to a very general analysis of structural and macroeconomic adjustments of a small open economy to an exogenous shock. While some of the voluminous literature on this subject over the past four decades commences with a reference to one or both of these papers, this model has become so much a part of the core body of general equilibrium economics that it is frequently used now without any reference to its origins.

\section{Macroeconomic Crises and Adjustment}

The 1980s was the decade of debt and crisis in much of the developing world, triggered by three interrelated events: rising global real interest rates, as the US Fed under Paul Volcker stiffened its resolve to fight inflation; the collapse of OPEC and the sharp decline in global oil prices; and the fiscal profligacy 
and rising debt of many developing country commodity exporters during the 1970 s boom. There was arguably no better place to work on these issues at that time than Washington DC, and that is where Max lived for 15 years from 1986 after moving initially (on leave from ANU) to a six months appointment at Harvard (Chair of Australian Studies) and then to the newly created position of Senior Advisor in the IMF's research department.

As he notes, the 'hot, current issues' in the IMF then were the Latin American debt crisis and the various proposals for debt relief. The latter involved the then novel proposal for some sort of international debt facility, under which the debt of crisis-afflicted countries could be purchased at a discount. Among the many complex questions were who would own (and pay for) the facility, and what sort of policy conditionality would be negotiated with the debtor countries. Max set to work on these issues in the Fund with a background paper, which was initially considered too sensitive for public release. The essential elements of his proposed solutions in fact anticipated what subsequently became known as the Brady Plan (named after the then US Treasury Secretary). Once the Brady plan was in the public arena, the Corden paper could be then released, appearing in 1988 in the Fund's Staff Studies, as 'An International Debt Facility?'

Max stayed in Washington DC for a further 13 years, taking up a position at Johns Hopkins' SAIS. There he taught courses on the international monetary system and international monetary theory while also very actively involved in policy discussions at the IMF and the World Bank. His major project initially was a large and ambitious World Bank project, the brainchild of Anne Krueger, involving 18 developing countries on Boom, Crisis and Adjustment, jointly with old friends, Richard Cooper (Harvard) and lan Little (Oxford), and Sarath Rajapatirana (World Bank), a former student who later became a close friend. Building on his analytical macro work and on familiarity with several Latin American and Southeast Asian countries, the project led to an extended immersion in the economic and political history of the 18 economies, with special reference to inflation and exchange rate policies. Of particular interest 
were the cases of hyper or at least extended high inflation, such as Argentina and Indonesia, and their macroeconomic and political economy origins. ${ }^{9}$

Max ended up becoming the project's key intellectual driver. In particular he brought in the Australian model as the unifying theoretical framework for the analysis of macroeconomic imbalances in these economies. That is, they all had the basic characteristic of 'dependent' economies, in that their terms of trade could be treated as exogenously determined. Max's demonstration of the flexibility of the model and its applicability to address a range of adjustment issues came as a surprise to many economists whose training had been in conventional 'large country' macroeconomics. Arguably, his contribution was an important factor in the subsequent widespread acceptance and popularity of the model among both practitioners in institutions such as the IMF and the World Bank, and among academic economists globally, becoming a standard model for the analysis of the macroeconomics of small open economies. ${ }^{10}$

Max was somewhat disappointed that the project's final synthesis volume (Little, Cooper, Corden, Rajapatirana 1994) did not have as much impact as he had hoped for, compared for example to the earlier OECD and NBER

9 Both countries indirectly had an Australian connection for Max: Argentina because of its historical similarities but subsequent diverging economic fortunes, and Indonesia because of its geographic proximity and the ANU academic focus on it.

Max had in fact co-authored two papers in regional economics journals on Indonesia, with Melbourne/ANU colleagues Jamie Mackie (1964) and Peter Warr (1981). The first focused on the exchange rate regime in the context of rising inflation and multiple exchange rates, the second on the oil boom.

He also wrote papers on the trade and balance of payments of other Southeast Asian economies, notably Malaysia and Thailand, in the 1960s.

10 As a recent illustration of its utility, Schmitt-Grohe and Uribe (2020) drew attention to its wide use and continuing relevance. 
multi-country projects on trade and exchange controls. ${ }^{11}$ The trade and exchange control studies were narrowly focused on essentially a single issue, whereas the nature, roots and the 'cure' (recovery policies) in the case of macroeconomic crises differed widely across countries, and episodes even in the same country. There was no single, simple message that could be distilled from the studies. Like Tolstoy's unhappy families, each crisis was different in some ways, precluding simple generalizations.

Nevertheless, his intimate involvement in the analyses of a wide range of crises from a large number of countries led him to revise his previous views about the attitude to large scale private foreign borrowings, and the issues surrounding global debt markets. He pointed out that private agents can be prone to excesses, that euphoria was a problem not only for private and government borrowers but also for lenders, and that in a turbulent world governments must expect and plan for unexpected shocks. He noted that governments often implement expansionary policies on the assumption that prevailing favourable conditions (such as positive terms of trade, capital inflows, cheap international credit) will persist in the long term. That is, 'temporary' positive shocks are presumed to be 'permanent'. When shocks reverse, spending (and real wages) are downwardly rigid, and economies plunge into crises. Max drew some general 'common sense' pragmatic policy conclusions from these studies that were to shape his response to his subsequent work on economic crises and policy recommendations. Above all, governments need to be cautious and prudent.

In fact, Max's last major book, Too Sensational: On the Choice of Exchange Rate Regimes, ${ }^{12}$ based on his 2002 Ohlin Lectures, synthesized much of his thinking on exchange rate regimes and macroeconomic policy options. With special focus on developing economies, he engaged again with the sometimes heated debate on the choice of exchange rate regimes, across the

\footnotetext{
11 These are widely known by the names of their key intellectual organizers, the Little-Scitovsky-Scott and Bhagwati-Krueger studies respectively 12 And surely also his catchiest book title, in deference to Oscar Wilde.
} 
spectrum from freely floating to 'hard peg' currency board options. He argued (convincingly in our view) for a pragmatic intermediate solution of managed float regimes, supplemented if necessary - in the presence of rigidities and other market imperfections - by cautious and moderate interventions in international capital markets. He also again emphasized the importance of the mix of expenditure switching and expenditure reducing policies when countries are forced to adjust to a long-term ('permanent') negative shock, and the central role of exchange rate policy in helping a country avoid unemployment when wages are downwardly rigid.

\section{More Economic Crises}

From a personal point of view, Max's involvement in the study of economic crises paid off as, contrary to the expectations of many, economic crises not only continued but acquired greater depth and breadth over the past quarter century. When the Asian Financial crisis (AFC) erupted suddenly in 1997, Max was well prepared to both analyse crises and suggest policies for coping and recovery.

As the global economy has continued to be subject to shocks and crises, understanding economic crises and their resolution has continued to be a major preoccupation of policy makers and the international financial system, Max has been in constant demand on the international lecture circuit. During the AFC, he delivered an influential Singapore lecture in 1999 ('The Asian Crisis: Is There a Way Out?'), followed by a retrospective on lessons learnt a decade on as an ANU Arndt Lecture ('The Asian Crisis: A Perspective after Ten Years'). In passing, these two lectures provided an opportunity to reflect on the role of the IMF. In a characteristically even-handed fashion, he pointed to its fundamental importance in the global economy and its many impressive staff members, alongside a recognition that the critics of the Fund's handling of the AFC indeed 'had a case'.

The 2008-09 global financial crisis (GFC) further extended Max's interest in the big issues of global macroeconomics. He recognized the possibility of a deep and prolonged recession, even another Great Depression, and was 
deeply concerned about the social and political consequences of such a catastrophe. In a burst of productive activity, he immediately set to work on analysis and writing, publishing four journal articles on aspects of the crisis, including in The World Economy, the Economic Journal, and elsewhere (Corden 2009, 2010, 2011, 2012). These papers addressed the roots of the credit crisis. In these Max also passionately advocated what he termed 'Ambulance Economics' - a massive Keynesian global stimulus effort to deal with the 'emergency' to avert a plunge into a deep and prolonged recession. He also pointed out that, although the crisis was a consequence of unsustainable debt, because of the 'paradox of thrift' the required policy response was an increase (not a decrease) in spending.

Max made a prominent contribution to the debates in Australia and elsewhere on whether the current account 'mattered', in particular whether the current account deficit should (and indeed could) be a policy target? Here, initially, he was in broad sympathy with the 'modern mainstream' view that, since the current account balance is the result of the independent actions of well informed savers and investors, there is no case for government intervention. However, he was careful to attach various caveats to this conclusion, as always emphasizing that the answer depended on the presence or absence of market distortions. Extending the arguments developed in his Ohlin Lectures, as the many distortions of global capital markets became increasingly visible, he recognized the need for governments to be prudent in managing international debt levels and capital flows, cautioning against excessive borrowings by governments as well as by the private sector.

As he followed the sluggish post-GFC recovery in North America and Europe, Max became keenly interested in the Japanese economic experience of 'stagnation', and the failure of the economy to respond to two decades of both conventional and unconventional expansionary monetary and fiscal policies. He was intrigued by the low levels of capital outflows from Japan, despite low yields at home and open capital markets, to take advantage of better longterm investment returns. Such outflows would have an immediate positive impact on the economy by depreciating the currency and stimulating the 
tradables industries, while providing a longer-term benefit through higher yields. In seeking to uncover the 'distortion' that inhibited larger outflows, he became interested in institutional aspects of Japanese financial markets, and Richard C. Koo's 'balance sheet recession' analysis. He also drew attention to what he regarded as Japanese savers' 'home country bias'. With one of the authors of this paper Max wrote a paper (Corden and Jayasuriya, 2016) arguing that, as the private markets failed to produce adequate levels of capital outflows, the Japanese government should consider establishing a sovereign wealth fund that could lend out domestic savings to engineer the required capital outflow.

In his macroeconomics, as in all matters of policy, Max has been a pragmatist. He has described himself as 'short term Keynesian and medium term neo-classical' recognizing that there is a role for active demand management during times of deficient aggregate demand. This is consistent with his overall approach to economics: 'I am not committed to markets at all costs. I am aware of market failures as well as the virtues of the market.' He has often pointed out that his major work on trade policy (Trade Policy and Economic Welfare) is devoted primarily to how policies can address distortions and other market failures.

\section{Australian Economic Policy}

As noted, and as emphasized in his memoirs, Max employed Australian economic policy issues to build durable international intellectual contributions. Australia was also the one country where he was significantly involved in public policy debates. Many of his papers were published in the Economic Record (the journal of the Economic Society of Australia) and other local publications, and therefore did not attract a wider international audience. ${ }^{13}$ But

${ }^{13}$ The key papers through to the mid-1990s are published in his The Road to Reform: Essays on Australian Economic Policy, 1997, a collection assembled 
as Kym Anderson notes in the introduction to the volume referred to in this footnote, Max's work '... has had an extraordinary impact on the on-going economic policy debate in Australia, on Australian professional opinion, and on actual policy outcomes.'

For a generation of students The Australian Economy: A Volume of Readings (1963), co-edited with Heinz Arndt, was their guide to the Australian economy and policy issues. Max actually dates his first major foray into the public policy domain as a 1958 Adelaide lecture entitled, 'Import Restrictions and Tariffs: A New Look at Australian Policy', which attracted wide media attention. It introduced the audience to the case for a uniform tariff structure, the gradual tariffication of non-tariff barriers, the link between tariff policy and the exchange rate, the importance of policy transparency (particularly relating to the costs of protection) and the beginnings of his methodological approach to the estimation of effective rates of protection. More than any other academic economist, he was the key intellectual figure behind the country's transformation from a highly inward-looking economy to one with minimal international trade barriers. That is, he provided the intellectual ammunition for reformers inside the bureaucracy and among the political class to wage a long battle to dismantle a protective system built up over many decades that was sustained by powerful vested interests. ${ }^{14}$

with the assistance of Kym Anderson, and which also includes some additional reflections by Max.

14 The reform story is explained in great detail by one of the key bureaucrats, Alf Rattigan (1986). The major reforms were not introduced until the mid 1980s under Prime Minister Bob Hawke. The fact that it took 30 years for the reforms to be introduced is testimony to the power of the protectionist lobbies. Modestly, Max attributes the success of the reforms to Rattigan and a colleague ('two admirable - indeed outstanding - public servants'), to Hawke himself, and to the latter's principal economic advisor (and a close friend mentored by Max), Ross Garnaut.

In passing it is interesting to note the parallel observations with other distinguished academic contemporaries of Max who, in very different political 
Max's other major policy contributions were in macroeconomics and wage policy. In the mid-1970s Australia was experiencing the twin (interrelated) challenges of a commodity boom and a wage explosion. He extended this analysis to wage policy. In his 1978 Presidential Address to the Economic Society of Australia (published later in 1979) he argued that Australia's unemployment was not Keynesian demand-deficient unemployment but unemployment caused by 'too high' real wages, relating it to union power in the country's centralized wage setting system. In a follow up 1980 paper with one of the country's leading economic modelers, Peter Dixon, he made the case for a de facto incomes policy through a tax-wage bargain as an alternative to conventional demand management to curb wage growth and ameliorate rising unemployment. (This also produced a 1981 Economic Journal paper.) This basic approach was later adopted by the Hawke government in a grand bargain with unions, employers and the government, known as 'The Accord'.

As noted, analysis of the commodity boom led directly to his major contributions to Dutch Disease economics. His macroeconomic analyses have also been referred to above, particularly related to the current account deficit and fiscal stimulus measures during the GFC. Australia's aggressive fiscal stimulus measures in 2009 contributed to the country having one of the mildest recessions in the OECD.

\section{Summing Up: the Personal and the Professional}

Max Corden is an exemplary model for any aspiring young economist: using theory as the basis for analysis and policy prescriptions, his clarity of thought

contexts, had to wait decades for their early advocacy for trade liberalization to result in policy reform. Examples include Jagdish Bhagwati in India and Gerardo Sicat in the Philippines. 
and exposition, a deep immersion in the institutional and practical realities of the subject matter, and a capacity to combine both 'big picture' analysis and attention to the nuances and caveats that need to be attached to the main arguments. In this sense, methodological approaches are important but secondary. Max's preferred expository tool is his beloved geometry, in preference to the current mainstream preference for mathematics (algebra). However, he recognizes the utility of mathematics in the exposition of theoretical models, and of statistical and econometric methods in empirical research ${ }^{15} 16$ (and after all, geometry is a branch of mathematics!).

Moreover, he has consistently demonstrated the utility of economics as a discipline that helps to understand and improve the state of the world. As Martin Wolf of the Financial Times, the world's foremost economics columnist, and a student of Max's, puts it in the foreword to the memoirs, '... I already believed [that] Economics was a political subject. Its proper aim was to make the world a better place. With his deep interest in practical questions, Max taught me that this was an altogether reasonable ambition.'

Clearly Max's personal history influenced his approach to Economics and the subjects he worked on. Although he wasn't personally deeply traumatized in his youth, he absorbed the lessons from pre-War Germany, of how deep economic crises can have devastating socio-political consequences. This shaped his macroeconomic policy thinking, including the importance of crisis avoidance as much as possible (meaning fiscal prudence and moderate debt), and the introduction of protective and stimulus measures when crises do occur. He has also viewed Economics as a powerful tool for social

15 See for example his joint papers with Peter Dixon and Peter Neary referred to above.

16 Although in his 2006 conversation with William Coleman he speculated (perhaps idly) whether he would now join the Economics profession: 'I was good at mathematics at Melbourne High, but I wasn't naturally mathematical as an economist. If Economics had been what it is now I probably wouldn't have gone into it.' 
progress, through better economic policy. His concern for the marginalized members of society led him towards the 'conservative social welfare function', for example. And although not actively engaged in the policy world, he has consistently sought to draw out the policy implications of his research. In his words, 'Right through my career as an economist, my choice of research topics has been determined by current events and policy issues.' Moreover, his work has had a global impact through its analytical power and originality, buttressed by his diligence and clarity of exposition.

Max's intellectual curiosity and enthusiasm for the subject matter are further illustrated by his love of teaching. (In contrast to academic administration which, by his own admission, was definitely not his forte.) To quote Wolf again, 'Max was far and away the best teacher and most lucid expositor I met during my time at Oxford.' The quality of his teaching has been recognized in various ways, including four Excellence in Teaching Awards at Johns Hopkins SAIS, and his lifetime collaboration, formal and informal, with his many former students from his earliest days at Melbourne onwards.

Max was a proselytizer for good policies (and causes), but apart from a brief membership of the Melbourne University Australian Labor Party club in his undergraduate years he was never politically active. He is self-described as 'left of centre' (especially in the US political context). He might be regarded as a 'classical liberal', and a humanitarian, especially on issues close to his heart such as the treatment of refugees. (He has contributed quietly and generously to various refugee-support groups.)

He has received numerous awards and honours. In 2002 he was appointed a Companion of the Order of Australia, the country's highest civilian award. ${ }^{17}$ The contributors to the two festschrifts in his honour (Kierzkowski (ed, 1987) and Rajapatirana and Riedel (eds, 2003), the latter a special issue of this

17 Perhaps also indicative of his political outlook, he records that his most valued congratulatory message came from the reforming former Labor Prime Minister Gough Whitlam. 
journal) comprised a virtual who's who in the fields of international and macroeconomics at the time. In 1986 he was awarded Kiel's Bernhard Harms Prize. In his work he was greatly supported and sustained by his life partner, Dorothy.

\section{References}

A complete list of Max Corden's publications can be found at his personal website, www.maxcorden.com

Amiti, S. S. Kong and D. E. Weinstein (2021), 'Trade Protection, Stock-Market Reforms, and Welfare', Center for Economic Policy Research Working Paper, Colombia University.

Anderson, K. (2003), 'Measuring Effects of Trade Policy Distortions: How Far Have We Come?', The World Economy, 26 (4), 413-440.

Berglas, E and A. Razin (1973), 'Real Exchange Rate and Devaluation', Journal of International Economics, 3(2), 179-91.

Coleman, W. (2006), 'A Conversation with Max Corden', Economic Record, 82 (259), 379-395.

Corbo, V. and S. Fisher (1995), 'Structural Adjustment, Stabilisation and Policy Reforms: Domestic and International Finance', in J. Behrman and T. N. Srinivasan (eds), Handbook of Development Economics, Volume III, pp. 2846-2924.

Corden, W.M. (2009), 'The World Credit Crisis: Understanding it and What to Do', The World Economy, 32 (3), pp. 385-400.

Corden, W.M. (2017), Lucky Boy in the Lucky Country. The Autobiography of Max Corden, Economist, Palgrave Macmillan.

Corden, W.M. and S. Jayasuriya (2016), 'The Japanese Macroeconomic Mystery', in H. Hill and J. Menon (eds), Managing Globalization in the Asian Century. Essays in Honour of Prema-Chandra Athukorala, ISEAS, Singapore, pp. 297-332.

Dornbusch, R. (1974), 'Real and Monetary Aspects of the Effects of Exchange Rate Changes', in R. Z. Aliber (ed), National Monetary Policies and the 
International Financial System, University of Chicago Press, Chicago, pp. 64-81.

Dornbusch, R. (1980). 'Home Goods and Traded Goods: The Dependent Economy Model', Chapter 6 in Open Economy Macroeconomics. Basic Books, New York, NY, pp. 93-118.

Greenaway, D., \& Milner, C. (2003), 'Effective Protection, Policy Appraisal and Trade Policy Reform', World Economy, 26 (4), 441-456.

Horne, D. (1964), The Lucky Country. Australia in the Sixties, Penguin, Sydney.

Kierzkowski, H. (ed.) (1987), Protection and Competition in International Trade: Essays in Honour of W.M. Corden, Basil Blackwell, Oxford.

Little, I.M.D., R. Cooper, W.M. Corden, S. Rajapatirana (1993), Boom, Crisis and Adjustment: The Macroeconomic Experience of Developing Countries, Oxford University Press, New York, for the World Bank.

Metaxas, P.E. and E.J. Weber (2016), 'An Australian Contribution to International Trade Theory: The Dependent Economy Model', Economic Record, 92, 298, pp. 464-497.

Rajapatirana, S. and J. Riedel (eds) (2003), Festschrift in Honour of Max Corden: Trade, Exchange Rate Regimes and Macroeconomics, The World Economy, 26(4).

Rattigan, A. (1986), Industry Assistance: The Inside Story, Melbourne University Press, Melbourne.

Schmitt-Grohe, S. and M. Uribe (2020), 'Reviving the Salter-Swan Small Economy Model', NBER Working Papers 27447, National Bureau of Economic Research, Inc. 